\title{
Groundwater Analysis Using Vertical Electrical Sounding and Water Quality Tester in Sukolilo Area, Surabaya, East Java: Significant Information for Groundwater Resources
}

\author{
Fuad Aulia Bahri ${ }^{1}$, Hasibatul Farida Rismayanti ${ }^{1}$, and Dwa Desa Warnana ${ }^{1}$
}

\begin{abstract}
This research purpose to find out groundwater quality and environmental pollution that has occurred in aquifer of Sukolilo, Surabaya, East Java. Vertical Electrical Sounding is a geoelectric method to measure the resistivity of the rocks. This instruments is used to obtain subsurface information about aquifer depth. Water quality tester is used to know water quality by measuring acidity, conductivity, salinity, Oxidation Reduction Potential, and Total Dissolved Solid parameter. The result shows that aquifer has about 3.17 $m$ thickness and lied at 0.45 to $3.62 m$ with lithology of alluvium. Lithology changes toward the north shown by different depth of the layers of rock. There has been sea water intrusion in groundwater aquifer at Sukolilo area. It was shown by high salinity and high Total Dissolved Solid parameter of some water samples with the higher values $A$ approaching sea. Therefore, it can be concluded that water from the unconfined aquifer in Sukolilo was polluted and not worthy for consumption.
\end{abstract}

Keywords-Aquifer, Groundwater, Geo-electric, Water Quality.

\section{INTRODUCTION}

Surabaya is the second largest city in Indonesia that become center of commerce and service with high inhabitant mobility. One of the district in Surabaya is Sukolilo. This area continues to develop significantly in commerce, industry, and education sector. The development of an area synonymous with the high number of people which indicates an increasing of water necessity. Therefore, ground water exploration will be higher and it will decrease ground water supply in aquifer layer. This condition can cause sea water (bigger mass) intrusion into aquifer and make ground water become brackish water or brine water. The decreasing of ground water supply that happen in coast aquifer makes hydrostatic imbalance between ground water and brine water. Sea water intrusion occur when ground water hydrostatic pressure is lower [1].

Sea water intrusion is a form of pollution and impact in various aspects of life such as health problems, declining soil fertility, damage to building foundations, etc. [2] Therefore, it is necessary to study in order to determine groundwater aquifer layers that have been intruded by brine water.

The use of geophysics for engineering studies and water groundwater exploration has been growing over the last few years due to the rapid advances in computer software and associated numerical modeling solutions. The

${ }^{1}$ Fuad Aulia Bahri, Hasibatul Farida Rismayanti, and Dwa Desa Warnana are with Department of Geophysical Engineering, Institut Teknologi Sepuluh Nopember, Surabaya, Indonesia. E-mail:
Vertical Electrical Sounding (VES) has proved very popular with groundwater prospecting and engineering investigations due to simplicity of the techniques. The electrical geophysical survey method is the detection of the surface effects produced by the flow of electric current inside the earth. The electrical techniques have been used in a wide range of geophysical investigations such as mineral exploration, engineering studies, geothermal exploration, archeological investigations, permafrost mapping, and geological mapping.

\section{LITERATURE REVIEW}

\section{Groundwater}

Groundwater is a water found beneath the surface, precisely at the fracture and the gaps which exist in soil particles, sand, and rocks under the earth's surface. Groundwater is stored below ground level and move slowly in a very low pressure through geological formations soil, sand, and rocks called the aquifer. The ground water will not always be in the ground, this is because at some point the water will return to the surface or washed out to sea. Therefore, aquifer is a point where the ground water back to the surface from underground. Aquifer is a rock that is able to drain water such as gravel, sand, or sandstone (Figure 1). Aquifer there are naturally occurring and some are made by humans. Aquifers can also be used as a water supply for the community.

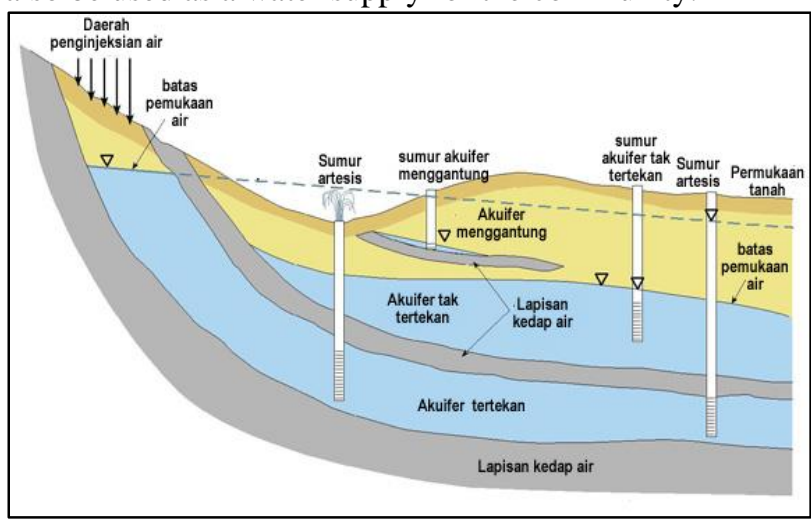

Figure 1. Groundwater Aquifer (Harlan et. al., 1989)

\section{B. Hidrogeology Surabaya}

Surabaya is a city with an area of approximately 33048 ha and is divided into four regions, namely Central Surabaya, East Surabaya, West Surabaya, and South Surabaya. Surabaya has 31 districts with 163 villages, a ground height of 0-20 meters above sea level, and a height of beach from 0-3 meters above sea level 
Surabaya city is dominated containing alluvial deposits composed of Tertiary rocks (Figure 2.). Kenjeran Mulyorejo aquifer layer is dominated by salty, brackish, and fresh water at the top. While there is a moderate productive aquifer at a depth of 40-100 meters with lithology clay sand, sand, and sand gravel. While in the area of Campus Stikom, it is known that there is a layer of salty and brackish aquifer at a depth of 0.44 to 5.48 meters. While moderate productive aquifer at a depth of 25-100 meters with lithology sand clay, sand, gravel and sand gravel which are called freshwater aquifers. In the area Margomulyo known the upper layer is dominated by a layer of salty aquifer, which is dominated by clay, sand, and gravel that have moderate until high value of porosity. At a depth of 40-100 meters below the surface is suspected freshwater aquifers.

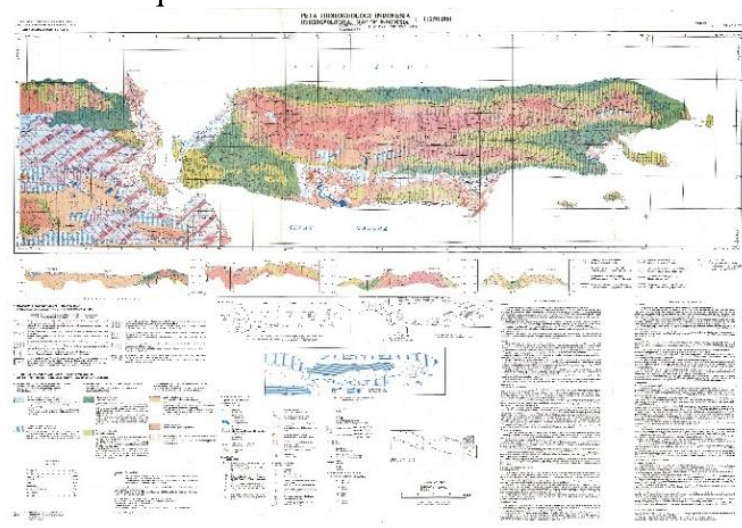

Figure 2. Hydrogeology map of Surabaya (Directorate of Enviromental Geology, 1986)

\section{METHOD}

The first method used in this research is Vertical Electrical Sounding (VES). VES or sounding method is 1D geo-electrical method of studying electrical resistivity properties of rock layer in the subsurface [3]. VES is active method because it takes injection of electric current into the Earth through two current electrodes then measures the potential difference through two potential electrodes [4] [5]. The configuration used in this method is Schlumberger configuration by setting the values of $\mathrm{AB} / 2$ and $\mathrm{MN} / 2$ as shown as (Figure 3 ) below

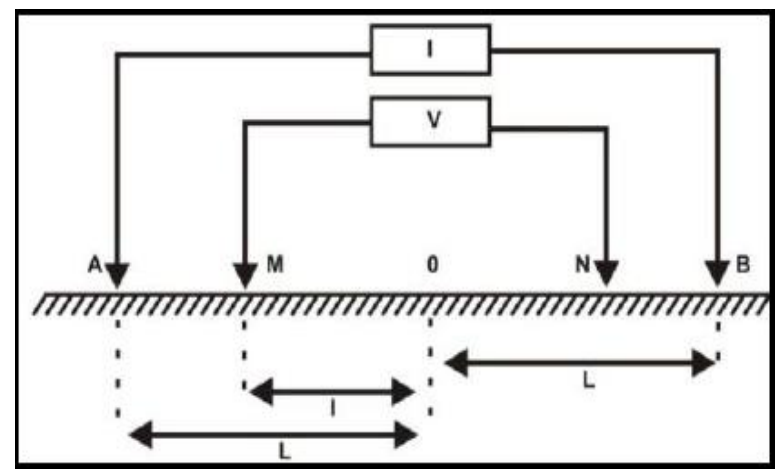

Figure 3. Schlumberger configuration (Telford, 1990)

Electrode (v) and current (I) value from measurements can calculate the resistivity $(\rho)$ of the rock using ohm law.

$$
\rho_{a}=k \frac{V_{m n}}{I_{a b}}
$$

$\mathrm{K}$ is a geometric factor, $V_{m n}$ voltage between $\mathrm{M}$ and $\mathrm{N}, I_{a b}$ current in the line $\mathrm{ab}$.

$$
k=\frac{2 \pi}{\frac{1}{r A M}-\frac{1}{B M}-\frac{1}{r A N}+\frac{1}{r B N}}
$$

There are three point measurement location of this research is Keputih area, Sukolilo, Surabaya.

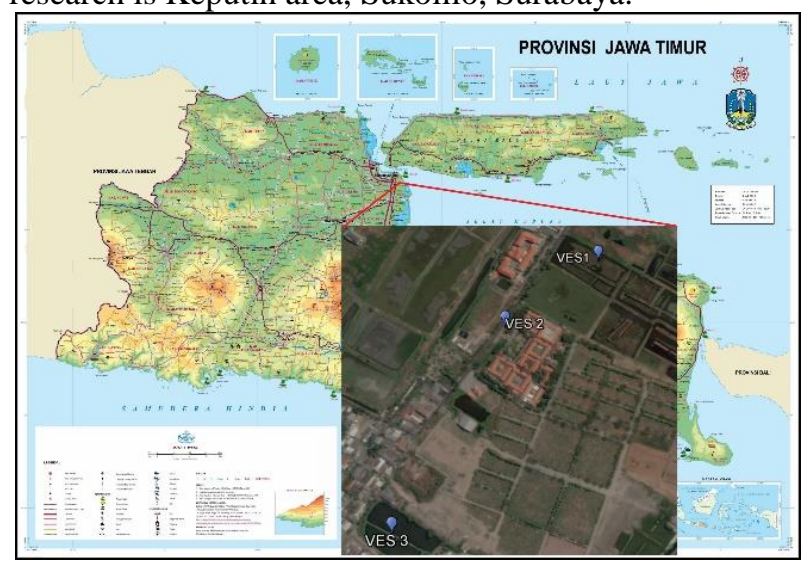

Figure 4. Measurement location (Source: Google Earth)

Data that obtained from this measurement are current and voltage which is processed by software IPI 2 win to get resistivity value and see subsurface section under sounding point. IPI2win is a open source software created by Alexey Bobachev, Moscow State University. Then, this subsurface section interpreted based on geology map and resistivity value in purpose to know each layer of lithology.

The second method is measurement of water quality using multi-parameter water tester tool. In this research, there are five ground water sample from five different wells. Parameters measured include acidity, conductivity, salinity, Oxidation Reduction Potential (ORP), and Total Dissolved Solid (TDS). Parameters that can be used as reference for the intrusion of sea water is salinity.

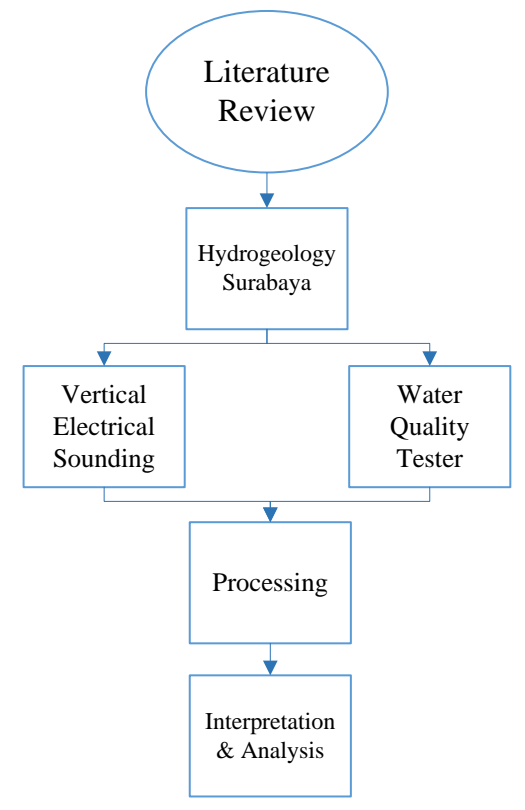

Figure 5. Methodology Flow 


\section{RESULTS AND DISCUSSION}

\section{A. Vertical Electrical Sounding}

The geometric factor, K, was first calculated for all the electrode spacings using the formula. Geometric factor multiplied with the resistance values to obtain the apparent resistivity values. Then the apparent resistivity, $\rho_{a}$, values were plotted against the electrode spacings $(\mathrm{AB} / 2)$ on a log-log scale to obtain the VES sounding curves using an appropriate computer software IPI2 win in the present research. The measurement has been done 3 VES acquisition in Sukolilo District with $\max \mathrm{AB} / 2=50$. After with some correction, data will processes into resistivity data.

From the measurement, author obtained the subsurface model after processing with error $9.17 \%$ VES $1 ; 9.44 \%$ VES $2 ; 8.89 \%$ VES 3. Conditions of location is swamp area. The measurement results obtained have a resistivity value of layer 1 through 4 , respectively, are 1.16, 0.958, 0.104 , and $92.6 \Omega \mathrm{m}$. According to a review on a geohydrology map, typology of Surabaya aquifer is alluvial typology. Based on the measurement that has been done was known, with suitability of the resistivity and author analysis that first layer is soil with 1-2 $\Omega \mathrm{m}$ resistivity. Second layer is unconfined aquifer with claysilt lithology which is located at a depth variation of 0.45 to $3.62 \mathrm{~m}$. this layer contains ground water with $0.5-1 \Omega \mathrm{m}$ resistivity. The thickness of this aquifer is about $3.17 \mathrm{~m}$. This layer like vadose layer or subsurface water. Third layer is clay-silt with $0.1-0.2 \Omega \mathrm{m}$ resistivity. This as a barrier layer on the water surface and the barrier of water on a layer of sand-silt. Fourth, layer is sand-silt with $>50$ $\Omega \mathrm{m}$ resistivity. This layer indicates the layers with compact rock or this layer has passed weathered rock layer. The depth penetration of this research reaches $40 \mathrm{~m}$. The subsurface section result is such this (Figure 5.)

There is a continuity from location of the swamp to final location, from north to south. The thickest layer unconfined aquifer is the location of the swamp VES 1. The lithology of layer changes from respectively from VES 1 until VES 3. All the layer depth rises. In the present study the authors do not get confined groundwater layer due to penetration lacking because there is no more vacant land. The result of this interpretation is reinforced by the correlation between the measurement results of VES data coring results SPT (Soil Mechanics Laboratory of Civil Diploma ITS, 2013).

\section{B. Water Quality Tester}

Water Quality tester has been conducted in this research, the measurement such as acidity $(\mathrm{pH})$, conductivity, salinity, ORP, TDS, and the depth of the ground water level. Water samples of soil were taken at six different wells are wells 1 and 2 located in the Gebang Lor, wells 3 are located within the campus of ITS, the well 4 in Jangkungan area, the well 5 in Nginden area. But every sample is still in the District of Sukolilo, East Surabaya. There are are 3 times measurements to make the data precisions.

The result of water quality tester shown that some ground water level samples in Sukolilo area are not worthy for consumption. It shows that some water samples (well 2 and 3) include brackish water. Brackish water is a compound of fresh water and brine water. It has salinity variety $500-35000 \mathrm{ppm}$ and acidity $(\mathrm{pH}) 6-8.5$ [6]. Based on the measurement, the salinity of well 2 and 3 sequentially are 553 and $661 \mathrm{ppm}$. The acidity are 7.55 and 8.13. Brackish water is not worthy for consumption because it has high chloride contents, that is $500-5000$ $\mathrm{mg} / \mathrm{L}$ [7].

Therefore, it can be a hypothesis that has been a sea water intrusion in groundwater aquifers at Sukolilo area. Given Sukolilo area is quite close to the sea, that is about $4.69 \mathrm{Km}$ distance. This hypothesis is reinforced by research conducted by Purnama S., et al [8] in 2006, it was known that Keputih (one of the regions in Sukolilo) detected a layer of brine water at a depth of $0.9 \mathrm{~m}$ until 5 $\mathrm{m}$ from the ground. To determine the dissemination of sea water intrusion, then made a counter map of salinity and it combined with measurement location map which took from Google Earth processed with spatial software (Figure 8). The sea water intrusion occurs in alluvium sediment and getting higher along with the close distance to the sea, as shown below. In this picture, the dark brown color shows greater water intrusion.

TABLE 1.

WATER QUALITY RESULT

\begin{tabular}{|c|c|c|c|c|c|c|c|c|c|c|c|c|c|c|c|c|c|c|c|c|}
\hline \multirow{2}{*}{ Well } & \multicolumn{20}{|c|}{ Measurements Parameters } \\
\hline & \multicolumn{3}{|c|}{ Acidity (Ph) } & \multirow{2}{*}{$\begin{array}{l}\text { Avg } \\
7.04\end{array}$} & \multicolumn{3}{|c|}{ Conductixix } & \multirow{2}{*}{$\begin{array}{c}\mathrm{Avg} \\
583\end{array}$} & \multicolumn{3}{|c|}{ Salinity } & \multicolumn{2}{|c|}{$\mathrm{Axg}$} & \multicolumn{2}{|c|}{ ORP } & \multicolumn{2}{|c|}{ Axg } & \multicolumn{2}{|c|}{ TDS } & \multirow{2}{*}{ Avs } \\
\hline 1 & 7 & 7.06 & 7.07 & & 587 & 578 & 584 & & 293 & 288 & 292 & 291 & 265 & 270 & 262 & 266 & 390 & 384 & 389 & \\
\hline 2 & 7.55 & 7.55 & 7.56 & 7.55 & 1187 & 1186 & 1183 & 1185 & 595 & 593 & 592 & 593 & 213 & 208 & 208 & 210 & 792 & 792 & 790 & 791 \\
\hline 3 & 8.14 & 8.12 & 8.14 & 8.13 & 1322 & 1325 & 1320 & 1322 & 660 & 662 & 660 & 661 & 204 & 205 & 205 & 205 & 882 & 882 & 880 & 881 \\
\hline 4 & 7.36 & 7.36 & 7.4 & 7.37 & 915 & 921 & 915 & 917 & 458 & 460 & 458 & 459 & 205 & 201 & 200 & 202 & 610 & 614 & 609 & 611 \\
\hline 5 & 7.58 & 7.55 & 7.58 & 7.57 & 636 & 640 & 645 & 640 & 320 & 321 & 322 & 321 & 188 & 189 & 189 & 189 & 428 & 427 & 429 & 428 \\
\hline
\end{tabular}


The $2^{\text {nd }}$ International Seminar on Science and Technology

August $2^{\text {nd }}$ 2016, Postgraduate Program Institut Teknologi Sepuluh Nopember, Surabaya, Indonesia

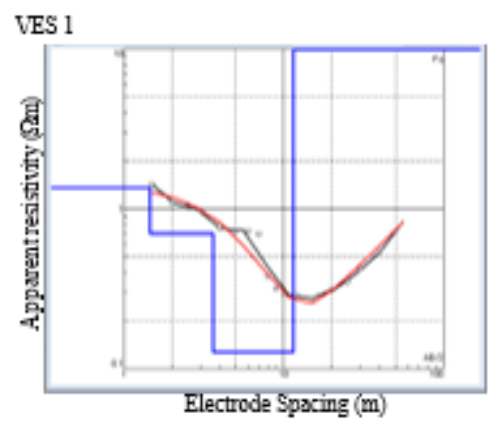

\begin{tabular}{|c|c|c|c|c|}
\hline \multicolumn{5}{|c|}{ Error : $9.17 \%$} \\
\hline No & $\rho$ & $\begin{array}{l}\text { Thickness } \\
\text { (m) }\end{array}$ & Depth (m) & Interpreted Layer \\
\hline 1 & 1.35 & 1.46 & $0-1.46$ & Soil \\
\hline 2 & 0.7 & 2.16 & $\begin{array}{c}1.46- \\
3.62\end{array}$ & $\begin{array}{c}\text { Aqufifer } \\
\text { Unconfined- } \\
\text { Typology Alluvium }\end{array}$ \\
\hline 3 & 0.127 & 7.94 & $3.62-11.6$ & Clay-Silt \\
\hline 4 & 51.3 & 57.94 & $7.94-30$ & Sand-silt \\
\hline
\end{tabular}

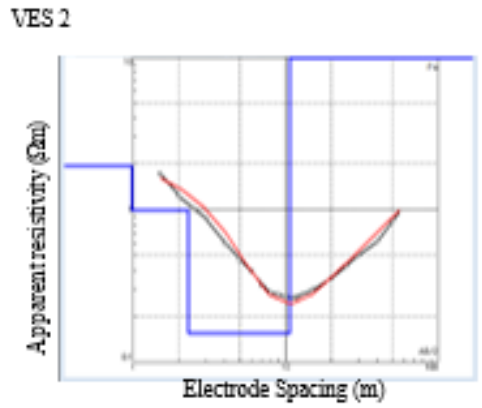

\begin{tabular}{|c|c|c|c|c|}
\hline & & Erro: & $: 9.440$ & \\
\hline No & $\rho$ & $\begin{array}{l}\text { Thichness } \\
\text { (m) }\end{array}$ & $\begin{array}{l}\text { Depth } \\
\text { (m) }\end{array}$ & Interpreted Layer \\
\hline 1 & 1.93 & 0.976 & $0-0.976$ & Soil \\
\hline 2 & 0.989 & 1.32 & $\begin{array}{c}0.976- \\
2.3\end{array}$ & $\begin{array}{l}\text { Aquifer Cicontine- } \\
\text { Typology Alluvium }\end{array}$ \\
\hline 3 & 0.154 & 8.36 & $2.3-10.7$ & Clay-Silt \\
\hline 4 & 105 & 5836 & $8.36-30$ & Sand-Salt \\
\hline
\end{tabular}

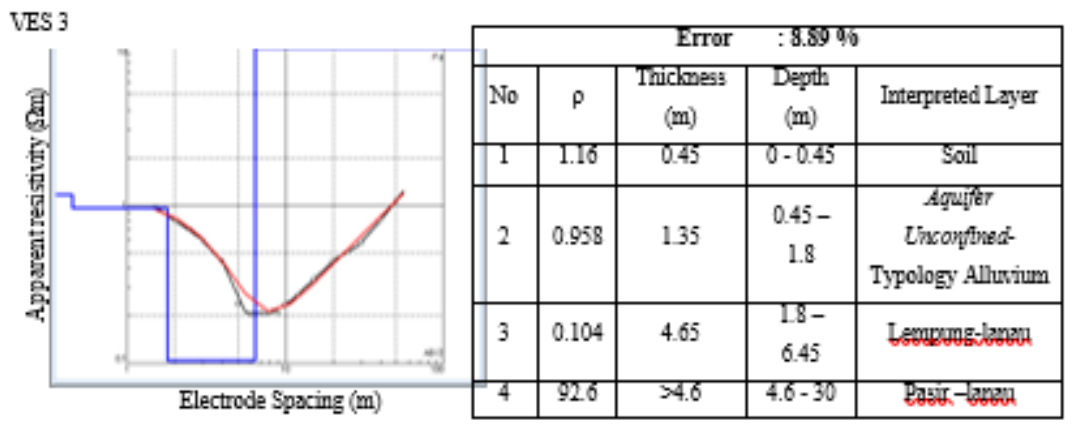

Figure 6. Typical curve types and models obtained from VES. Three resistivity sounding curve types were obtained from the studied area and these are the $\left(\rho_{1}>\rho_{2}>\rho_{3}<\rho_{4}\right)$
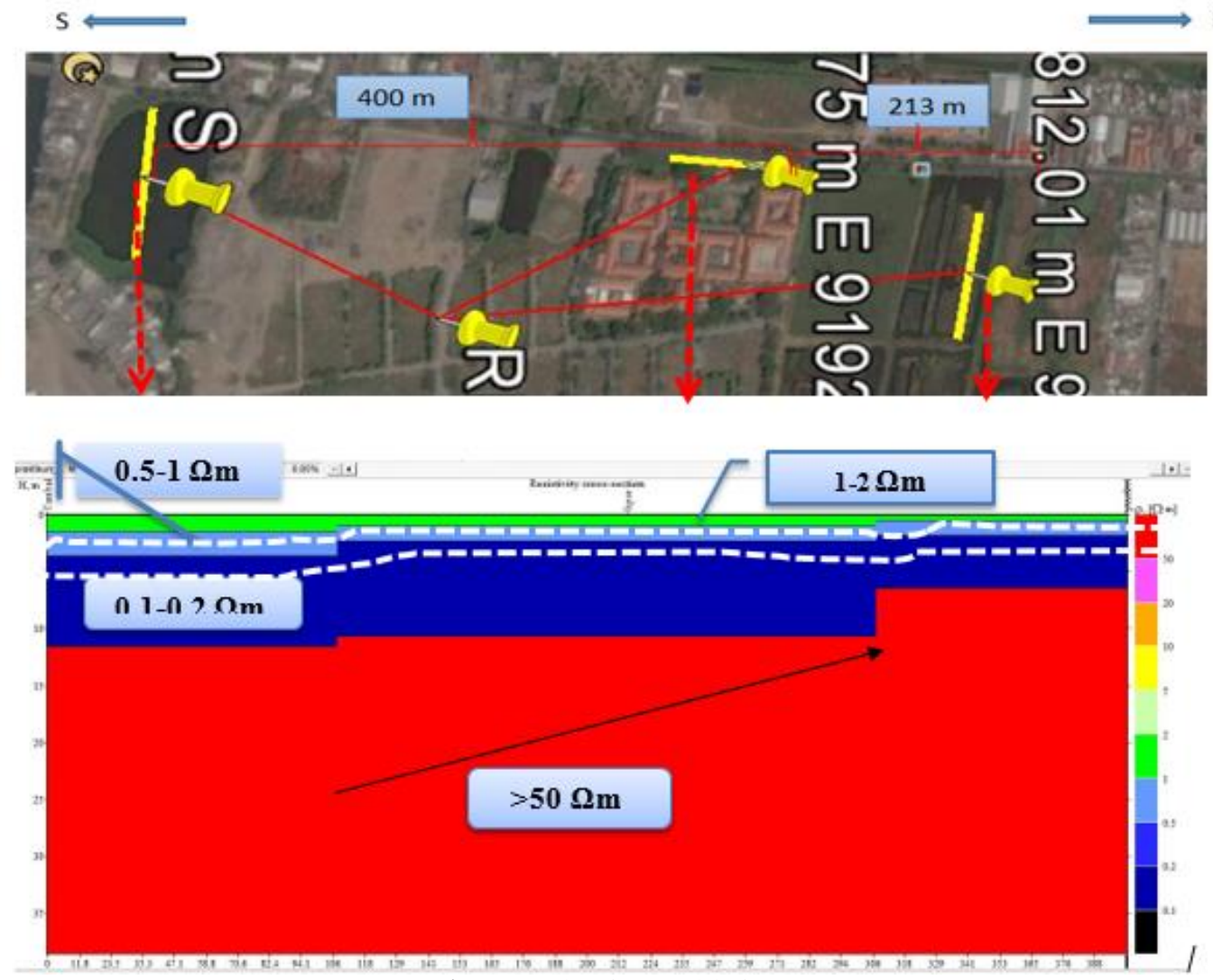

Figure 7. Subsurface Model of VES 


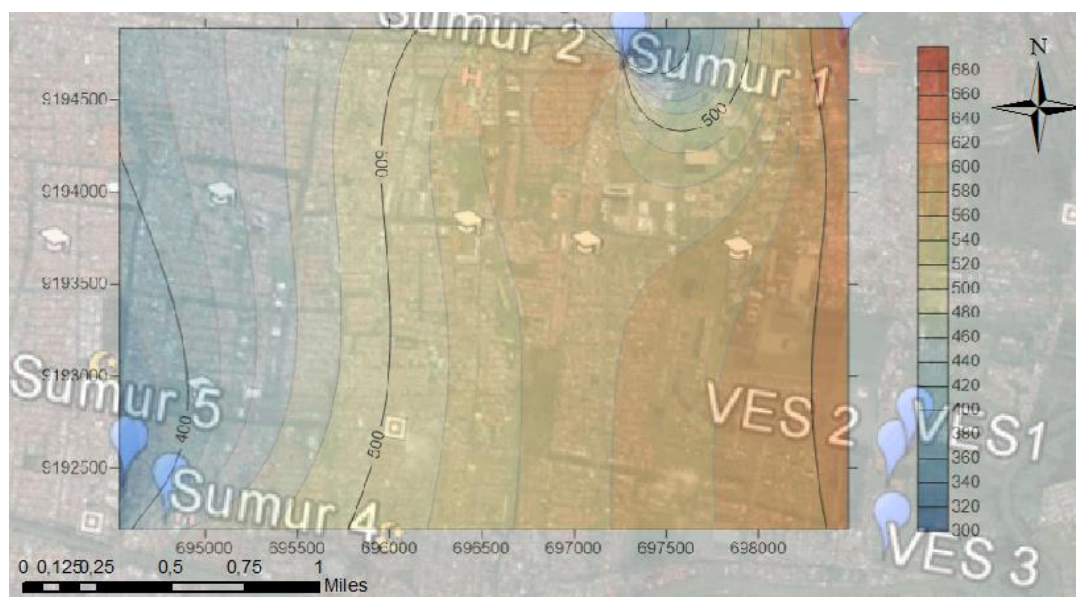

Figure 8. Overlay salinity contour map with Surabaya map

\section{CONCLUSION}

Based on the research that has been done, known that there has been sea water intrusion in ground water aquifer at Sukolilo area. It is shown by the high value of salinity and acidity of some water samples with increasing value toward the sea. This aquifer has about $3.17 \mathrm{~m}$ thickness and lied at 0.45 to $3.62 \mathrm{~m}$ depth. Therefore, it can be concluded that water from the unconfined aquifer in the Sukolilo district was polluted and not worthy for consumption.

\section{ACKNOWLEDGEMENTS}

The Authors wish to thank to Mr. Diptya, Mr. Adib, Mr. Fauzan, and Mrs. Nathasya who have helped in data acquisition.

\section{REFERENCES}

[1] Sosrodarsono, S. dan Takeda, S. "Hidrologi untuk Perairan”. PT. Pradnya Paramita, Jakarta. 2003.
[2] Saputra, S. 1998. "Telaah Geologi Terhadap Banjir dan Rob Kawasan Pantai Semarang”. Jurnal Ilmu Kelautan 3 (10): 85-92.

[3] W. M. Telford, et al., "Applied Geophysics". Cambridge University: Press New York.

[4] Aswathanarayana, U. "Geoenvironment - An Introduction". A. A. Balkema. Rotterdam. 1995.

[5] Ward, S. H. "Resistivity and Induced Polarization Methods, dalam Geotechnical and Environmental Geophysics". Vol. I, hal. 147. Tulsa: SEG. 1990

[6] Yusuf, E., T, A. Rachmonto., dan R. Laksmono. "Pengolahan Air Payau Menjadi Air Bersih Dengan Menggunakan Membran Reverse Osmosis". Jurnal Teknik Lingkungan. Fakultas Teknik Sipil dan Perencanaan. Universitas Pembangunan Nasional. Jawa Timur. 2008 Vol 1 (1): 6-15.

[7] Kusumahati,I. "Studi Kemampuan Resin Kation $\mathrm{Na}+$ dan $\mathrm{H}+$ sebagai Media Penukar Ion Untuk Menurunkan kandungan Tembaga“. Program studi Teknik Lingkungan. ITS. Surabaya. 1998.

[8] Purnama, Setyawan dan Sulaswono, Budi. "Pemanfaatan Tekni Geolistrik untuk Mendeteksi Persebaran Air Tanah Asin pada Akuifer Bebas di Kota Surabaya". Majalah Geografi Indonesia. 2006. $0125-1790$. 